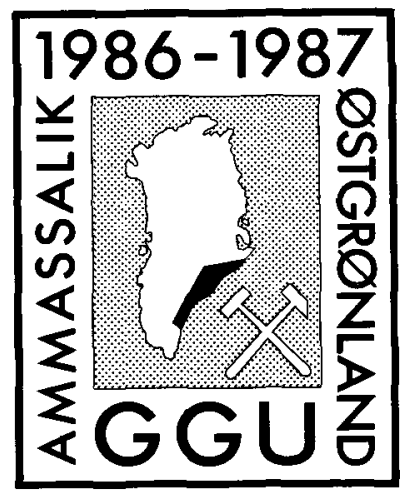

\title{
The northern boundary of the Proterozoic (Nagssugtoqidian) mobile belt of South-East Greenland
}

\author{
P. R. Dawes, N. J. Soper, J. C. Escher and R. P. Hall
}

\begin{abstract}
The Proterozoic mobile belt of South-East Greenland has been regarded as a classic example of amphibolite facies reworking of an Archaean granulite facies gneiss terrain. Its northern boundary has been interpreted as a transcurrent shear zone in which reworking was associated with major basic dyke emplacement. A re-examination of the northern boundary shows it to be a diffuse region more than $50 \mathrm{~km}$ wide in which retrogression, unrelated to dykes or shear zones, gradually intensifies southwards. Superimposed on this are discrete belts of retrogression associated with dykes and shear zones. The sense of displacement on the latter is compatible with thrusting of the northern Archaean block southwards over the reworked terrain of the mobile belt.
\end{abstract}

\section{Introduction}

The northern boundary of the Proterozoic mobile belt of South-East Greenland has previously been studied during regional mapping by teams headed by $D$. Bridgwater and later by J. S. Myers (Bridgwater $e$ t al., 1977, 1978a,b; Myers et al., 1979, 1980). In regional descriptions of the mobile belt (previously termed the Nagssugtoqidian belt) the northern boundary has been interpreted as being defined by a steeply dipping E-W zone of high deformation in which granulite facies Archaean (2800-3000 Ma) gneisses are retrogressed to amphibolite facies (Bridgwater \& Myers, 1979; Myers, 1984, 1987). The shear zones which make up this belt are the earliest (so-called Nag. 1) phase of Proterozoic deformation, dated at 2660 Ma (Pedersen \& Bridgwater, 1979). The shear zones have been described as showing transcurrent displacement and are associated with the earliest of several phases of syntectonic basic dykes. Nag. 1 structures are modified by Nag. 2 deformation which comprises folds and shear zones with a southerly overthrust vergence. A suite of NE-trending basic dykes (Charcot Fjelde dykes) were interpreted to have been intruded during the Nag. 2 deformation at around $1800 \mathrm{Ma}$ (Myers et al., 1979).

In this paper, we trace the history of geological ideas about the northern margin of the belt and, based on regional studies in 1986, discuss the geological relationships of the region between $66^{\circ} \mathrm{N}$ and $67^{\circ} \mathrm{N}$ (fig. 1). We interpret the northern boundary as a diffuse zone tens of kilometres wide, rather than a discrete mappable shear-zone line.

\section{Previous work and interpretation}

\section{Early reconnaissance}

The Precambrian terrain between $66^{\circ} \mathrm{N}$ and $67^{\circ} \mathrm{N}$ was reconnoitred in $1930-31$ by $\mathrm{L}$. R. Wager, mainly on a boat journey from Ammassalik $\left(65^{\circ} 30^{\prime} \mathrm{N}\right)$ to Kangerdlugssuaq $\left(69^{\circ} \mathrm{N}\right)$ and on an ice traverse to Mont Forel (Wager, 1934). He described the high-grade metamorphic complex with a dominant WNW-ESE strike and recognized the widespread presence of grey gneisses containing abundant plagioclase amphibolites, as well as areas of granulite facies gneisses ('hypersthene granite gneiss of charnockitic affinities'). A particular structure given prominence by Wager (op. cit., p. 18) is a WNW-trending zone of 'granulitization' and shearing in the Kangertigtivatsiaq area (figs $1 \& 11$ ) that he concluded "is probably a line of considerable tectonic importance". Wager described the zone as being several miles at least in width and with indefinite boundaries, recognizing that the period of shearing and associated retrogression represented a late stage in the formation of the metamorphic complex having taken place at high temperature and pressure. This zone is pertinent to later ideas about the northern boundary of the mobile belt.

Field work on foot in 1963 and 1966 by Wallis (1967) in the inland region, around the head of Sermilik, 16. September Gletscher, Glacier de France and northeastern Schweizerland, provided regional correlation with the reconnaissance stratigraphy of Wager (1934). Wallis recognized several generations of deformation 
Fig. 1. General location map of the region between Ammassalik and Kangerdlugssuaq showing area covered by the geological map of the northern boundary of the Proterozoic mobile belt - see fig. 3 .

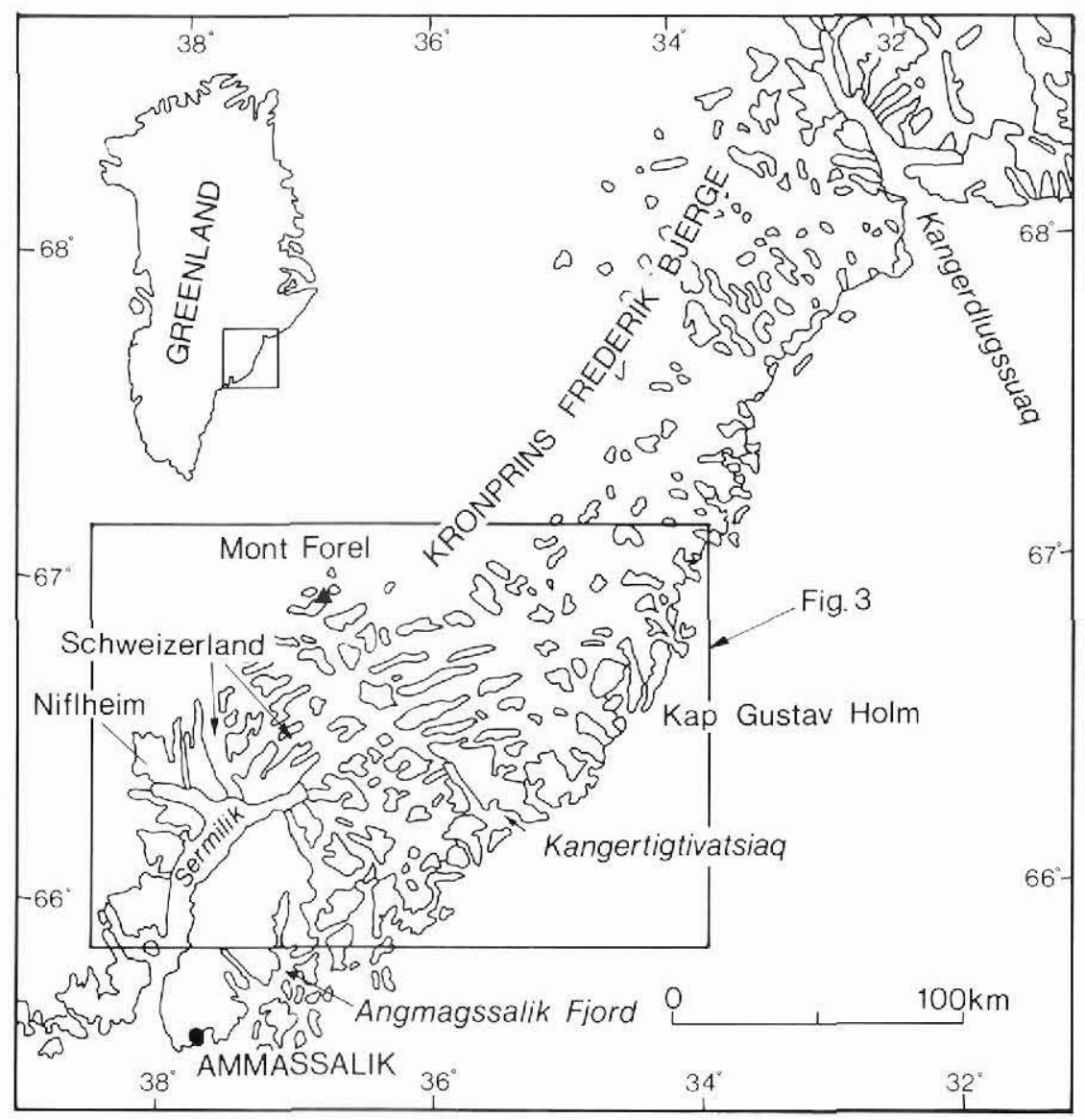

and basic dykes, including the NE-trending garnet amphibolites later referred to by Myers et al. (1979) as the Charcot Fjelde dykes. Of particular relevance to the present discussion is Wallis's observation that there is a striking change in the appearance of the mountains along a line north of the 16. September Gletscher; pale, well-foliated amphibolite facies gneisses containing metasediments and abundant meta-igneous material give way northwards to pink and red, rather homogeneous granulite facies rocks. "This junction zone is quite apparent to the eye on a large scale, but it is not so easy to define in detail on any one particular mountainside" (Wallis, 1967, p. 2). This WNW-trending zone is apparent on our geological map (fig. 3) representing the southern part of our diffuse boundary zone.

\section{Correlation with the Nagssugtoqidian of West Greenland}

Following boat reconnaissance in the Ammassalik area and to the south along the coast, Bridgwater \&
Gormsen $(1968,1969)$ erected a subdivision of the Precambrian terrain and recognized a northern block (north of $64^{\circ} 15^{\prime} \mathrm{N}$ ) that they argued was "affected by the eastern continuation of the Nagssugtoqidian orogeny" of West Greenland (Bridgwater \& Gormsen, 1969 , p. 43). The southern boundary of this unit (defined where Archaean structures and basic dykes cutting them were strongly deformed by linear shear belts) was highlighted in comparative studies of Proterozoic mobile belts both in and outside Greenland and the shearzone boundary-type came to be representative of the Nagssugtoqidian of East Greenland (Bridgwater et al., 1973 a, b; Andrews et al., 1973).

The GGU investigations, as well as field work by other institutions in the late $60 \mathrm{~s}$ and early $70 \mathrm{~s}$ (e.g. Wright et al., 1973) reached only as far north as the head of Angmagssalik Fjord (c. $66^{\circ} \mathrm{N}$ ) and for a number of years it was envisaged that the Proterozoic (Nagssugtoqidian) mobile belt formed the entire coast northwards to Kangerdlugssuaq where the crystalline shield disappears beneath Tertiary cover (Escher, 1972; Bridgwater, 1976; Escher \& Watt, 1976). 


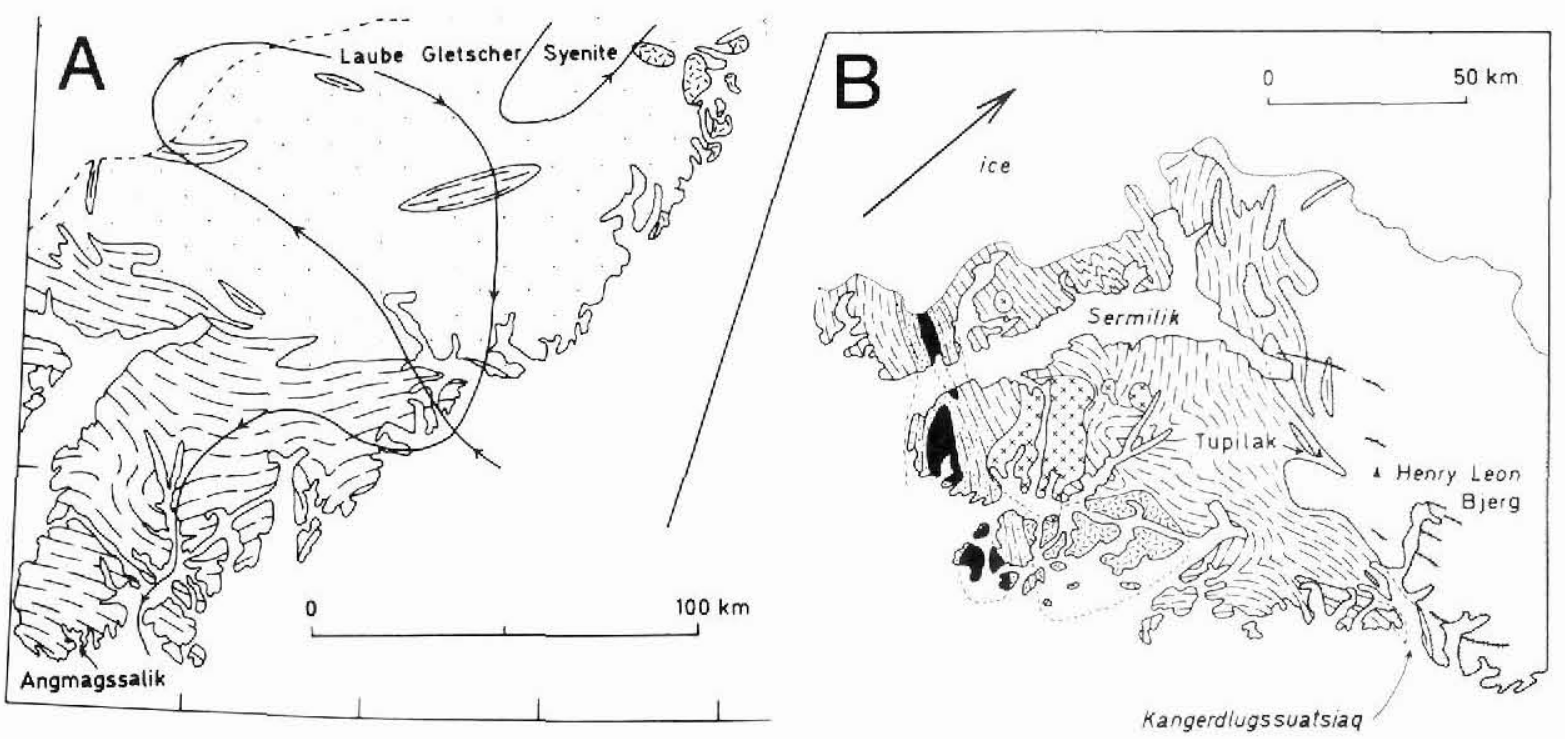

Fig. 2. Previously published geological sketch maps showing the northern boundary of the Nagssugtoqidian mobile belt trending WNW from the mouth of Kangertigtivatsiaq (Kap Japetus Steenstrup) to the Inland Ice. Both sketches (A \& B) are taken from larger illustrations. A: from Myers et al. (1980, fig. 30) illustrating areas of Nagssugtoqidian deformation (dashed ornament) within the Archaean craton to the north. Continuous line with arrows indicates the two fixed-wing aircraft routes flown by Myers in 1979. B: from Myers (1984, fig. 8; also Bridgwater \& Myers, 1979, fig. 1) showing locations of Tupilak and Henry Leon Bjerg (see figs 4 \& 10).

\section{Definition of the boundary}

Renewed GGU field work by boat during 1976 and 1977 between Ammassalik and Kangerdlugssuaq (first summers of a four year programme; Bridgwater et al., $1977,1978 \mathrm{a}, \mathrm{b}$ ), supported by isotopic dating work ( $\mathrm{Pe}-$ dersen \& Bridgwater, 1979), led to definition of the northern extent of the Proterozoic mobile belt and suggested correlation with Nagssugtoqidian events on the west coast. Prominent deformation events referred to Nag. 1 and Nag. 2 were traced in the coastal area as far north as the fjord Kangertigtivatsiaq $\left(66^{\circ} 15^{\prime} \mathrm{N}\right)$.

An increase in metamorphic grade north-eastwards along the coast was also recognized in 1976 and five metamorphic zones were outlined (Bridgwater et al., 1977 , p. 80). The most northerly zone between Depotfjord $\left(66^{\circ} 07^{\prime} \mathrm{N}\right)$ and the head of Kangertigtivatsiaq $\left(66^{\circ} 28^{\prime} \mathrm{N}\right)$ was designated "a zone of predominantly granulite-facies rocks" in which Proterozoic deformation is restricted to narrow shear belts. The main structure and planar fabric of the zone were regarded as Archaean elements "little modified by later movements" except for minor shearing. Based on the effects of deformation on basic dykes, an east-west boundary was drawn through Depotfjord separating, to the north, a terrain in which garnet amphibolite dykes appear as 'non-folded' linear bodies (not affected by Nag. 2), from the mobile belt to the south within which such dykes were deformed and broken up within Archaean gneisses (Bridgwater et al., 1977, fig. 19).

Following field work north of Kangertigtivatsiaq in 1977, the northern limit of the mobile belt was placed about $20 \mathrm{~km}$ north of Depotfjord "at an east-west vertical zone of high deformation about $2 \mathrm{~km}$ wide at Kap Japetus Steenstrup" at the mouth of Kangertigtivatsiaq (Bridgwater et al., 1978b, p. 87) (see fig. 11). This is the structure noted by Wager (1934); it was reinterpreted by Bridgwater and coworkers (1978a; Bridgwater \& Myers, 1979) to be a regional shear zone separating granulite facies rocks in the north from retrogressed terrain to the south (fig. 2).

The granulite facies Archaean block in the north, between the shear zone and Kangerdlugssuaq, was said to be "hardly affected by later regional deformation and metamorphism" (Bridgwater et al., 1978a, p. 5) "except for local well-defined narrow shear belts and fractures" (Bridgwater \& Myers, 1979, p. 10). The most northerly of these "few isolated sub-vertical belts of high deformation" were seen at $68^{\circ} 20^{\prime} \mathrm{N}$ in the Kangerdlugssuaq area while "low-dipping zones of high deformation" were noted between the northern margin and K. J. V. Steenstrup Bræer $\left(66^{\circ} 28^{\prime} \mathrm{N}\right)$ (Bridgwater et al., 1978a, p. 10). 


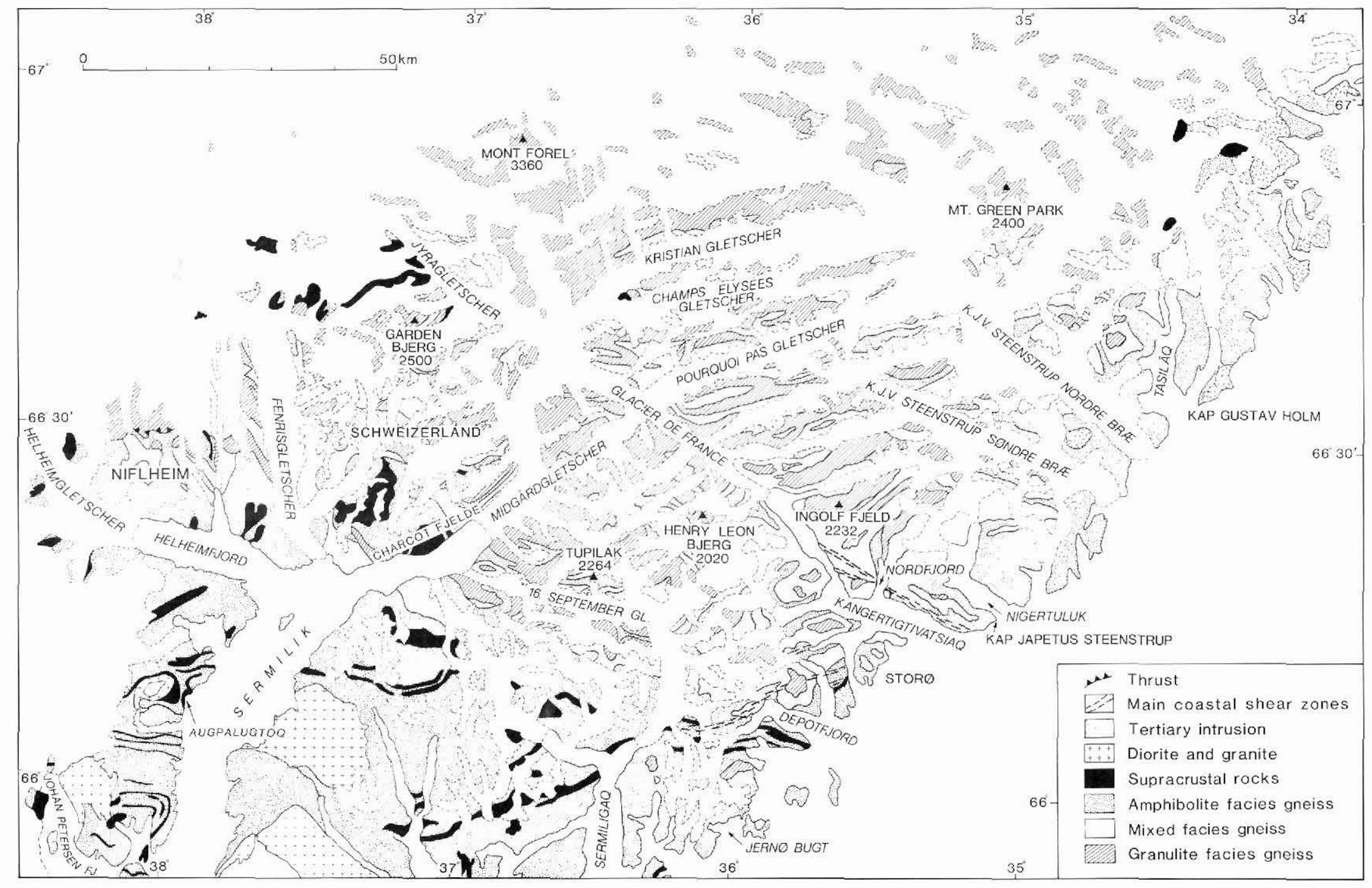

Fig. 3. Geological map of the northern boundary of the Proterozoic mobile belt based on mapping in 1986 illustrating the transition from the Archaean, dominantly granulite facies terrain in the north to the reactivated amphibolite facies gneisses within the mobile belt to the south. Three categories of gneisses are shown: granulite facies, mainly brown granulites with less than 25 per cent (vol.) retrogession; amphibolite facies, mainly grey gneisses containing less than 25 per cent granulite relicts; and mixed or partly retrogressed gneisses. 


\section{Mapping of the boundary}

Apart from an air-supported commercial investigation to as far north as $67^{\circ} \mathrm{N}$ (reported in Andrews et al., 1973), field work prior to 1978 was based on boat, sledge and foot traverses. In 1978 and 1979 - the last summers of GGU's four year programme - limited helicopter and fixed-wing aircraft support became available.

Thus, in 1978, on a single helicopter flight, an attempt was made to trace the Nagssugtoqidian boundary from the coast for $150 \mathrm{~km}$ westwards across rugged nunatak terrain from outer Kangertigtivatsiaq to the Inland Ice, north-west of the head of Sermilik (Myers et al., 1979; J. S. Myers, personal communication, 1986). The boundary was described as "a major zone of complex shear zones, basic dyke intrusion and retrogression of Archaean granulite facies to amphibolite facies rocks" (Myers et al., 1979, p. 82). The boundary was depicted on small-scale maps as a continuous but complex line (fig. 2) and described as being vertical along Kangertigtivatsiaq and dipping $40^{\circ}$ to the north near the Inland Ice.

In 1979 , the inland region north of $66^{\circ} \mathrm{N}$, including the eastern part of the northern boundary, was traversed on two fixed-wing aircraft flights. Within the Archaean granulite facies block "major lenticular zones of intense Nagssugtoqidian deformation and dyke intrusion were discovered between 40 and $80 \mathrm{~km}$ north of the mobile belt, similar to those found closer to the margin in 1978" (Myers et al., 1980, p. 87) (fig. 2).

\section{Summary of previous knowledge}

Published views of the northern boundary thus envisage an irregular but continuous, sharply defined roughly east-west shear-zone between Kangertigtivatsiaq and the Inland Ice separating granulite facies Archaean rocks in the north from the amphibolite facies reworked terrain of the mobile belt (Bridgwater \& Myers, 1979; Myers, 1984, 1987). This boundary interpretation, based on prominent shearing (and thus on a par with the tectonic model established for the Nagssugtoqidian in West Greenland) was proposed, although Wallis $(1967$, p. 5) had described the diffuse, large-scale passage from granulite facies to amphibolite facies terrains, and had categorically stated that "no major structural discontinuity was seen anywhere" in the inland region.

Outcrops of rocks affected by Nagssugtoqidian deformation and retrogression were recognized north of the boundary, and augen of unmodified Archaean gneiss were shown occurring within the mobile belt (fig. 2). In the context of the Nagssugtoqidian deformation model stressed previously in the literature, the boundary seems to have been interpreted as a complex of shear zones of Nag. 1 age, deformed by Nag. 2 to produce the mapped outcrop pattern.

\section{Present field work and mapping techniques}

In 1986, field work in the northern part of the mobile belt was carried out by two teams: PRD and NJS worked in the east (from a base at Nigertuluk) and JCE and RPH in the western part, north of Sermilik (from the Ammassalik base). The work was based on helicopter reconnaissance; the few foot traverses made were restricted to the easternmost and westernmost parts of the region, around Nigertuluk-Kangertigtivatsiaq and Niflheim, respectively (figs $1 \& 3$ ).

The inland terrain is exceptionally rugged, formed of ice-surrounded alpine peaks between 2000 and $3000 \mathrm{~m}$ high. Mont Forel is the highest peak $(3360 \mathrm{~m})$. Access to rock exposures, even by helicopter is restricted since landing sites on other than ice are few and far between. The regional mapping was accomplished by helicopter traverses during a 12 day period; the eastern team made use of helicopter for 5 days while the work in the west was based on 7 day's helicopter traversing. Mapping was undertaken on 1:150 000 aerial photographs with field compilation on 1:250 000 maps. In general, the work was concentrated in the inland regions, since earlier GGU reconnaissance maps exist for parts of the outer coast as far north as Kangertigtivatsiaq and from the head of Sermilik (fig. 3).

In addition to the blanket mapping of the Nagssugtoqidian boundary region between $66^{\circ} \mathrm{N}$ and $67^{\circ} \mathrm{N}$, three days were spent by PRD and NJS farther north on 'sit-in' helicopter traverses organised by other parties. These trips extended as far north as the little examined nunatak terrain of Kronprins Frederik Bjerge $\left(67^{\circ} 50^{\prime} \mathrm{N}\right.$, fig. 1$)$.

\section{Retrogression, shear zones and basic dykes}

The broad outline of the interpretation presented by Bridgwater \& Myers (1979) regarding metamorphic retrogression, shear zones and basic dykes in the region of the northern limit of the mobile belt was confirmed during the work in 1986. However, the boundary separating a northern Archaean block (granulite facies with restricted areas of retrogression) from a southern amphibolite facies block (mobile belt with some 'augen' of unmodified Archaean crust) proved to be a very diffuse zone more than $50 \mathrm{~km}$ wide. We found no regionally mappable boundaries, shear zones or otherwise, that 
Fig. 4. The mountain Tupilak (2264 $\mathrm{m}$ ) showing prominent patchy retrogression of granulite facies gneiss on the summit massifs, with retrogression parallel to lithological layering below. Height of the section is about $1000 \mathrm{~m}$; view is from the south.

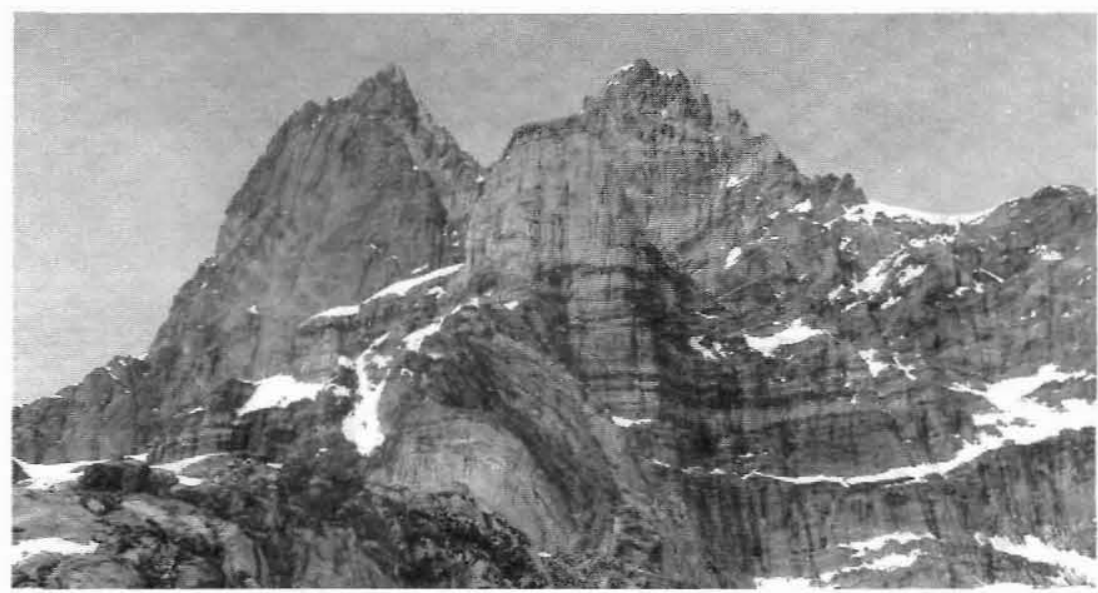

consistently separate different metamorphic terrains; rather, our observations confirm the findings of Wallis (1967). In our view, the idea that a major shear zone separates a northern granulite block from a southern retrogressed belt is an oversimplification.

The northern boundary of the mobile belt does coincide to a large extent with a zone of amphibolite facies retrogression of granulite facies gneisses. However. there is evidence of prograde, amphibolite to granulite facies metamorphism both north and south of the boundary (Bridgwater et al., 1977, 1978a), and large areas of amphibolite facies gneisses to the south show no evidence of ever having been at granulite grade. Thus, although retrogression of the granulite facies gneisses has occurred on a regional scale, not all areas of grey, amphibolite facies rocks represent Proterozoic retrogression of higher grade Archaean gneisses.

Four styles of retrogression have been recognized in the region straddled by the northern boundary:
(1) Wholesale, regional retrogression of granulite facies gneisses developed presumably during the waning stages of regional metamorphism, and resulted in the large majority of the granulite facies gneisses having variable amphibole/mica reaction coronas to orthopyroxene. Certain horizons within the gneisses appear to be preferentially retrogressed (fig. 4) although it is not known whether this reflects a simple lithological control or retrogression along closely spaced joint systems in variably deformed gneisses.

(2) Irregular 'network' or 'patchy' retrogression is common and occurs as anastomosing networks of pale grey retrogression zones which surround less altered patches of brown relict granulite facies gneisses (fig. 4). This type of retrogression occurs on all scales, and as noted by Myers (1984), it appears to be an early phase of alteration. It may be related to the first type of regional retrogression, and probably resulted from the hydration of the granulite facies gneisses along irregular
Fig. 5. Swarm of amphibolite dykes associated with severe retrogression of granulite facies gneisses. Although not visited on the ground, cataclastic effects in the gneiss west of the col suggest the presence of a shear zone. A dyke in the brown granulite facies gneisses on left is associated neither with shearing nor retrogression. Champs Elysées Gietscher; height of the section with dyke swarm is about $300 \mathrm{~m}$.

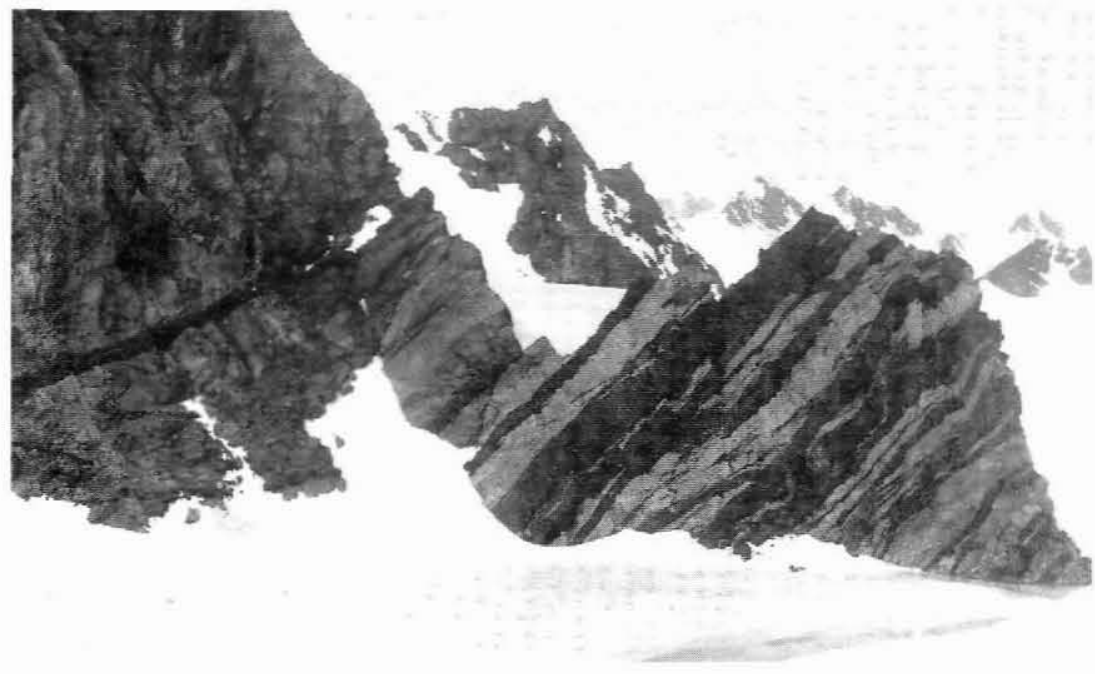




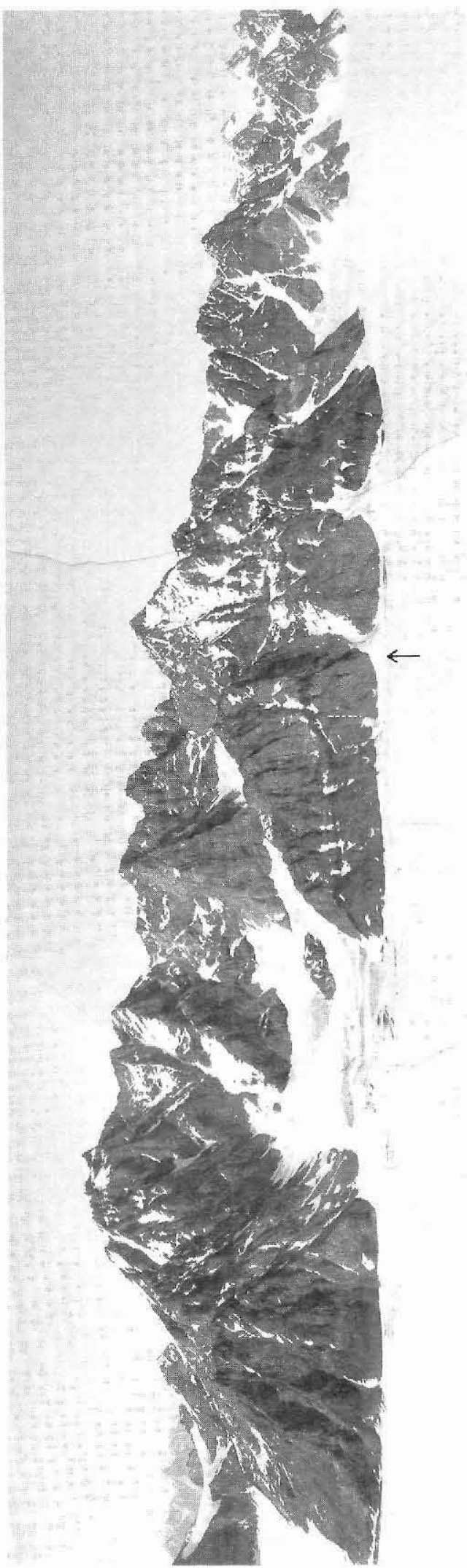

joint and fracture planes. These networks appear to be mainly independent of shear zones and bear no relation to the orientation or abundance of basic dykes. The belt of gneisses which have been subjected to network retrogression occupies a WNW-ESE trending zone some 50 $\mathrm{km}$ wide.

(3) As initially noted by Wager (1934), retrogression is associated with shear zones. Bridgwater \& Myers (1979) described the principal mode of retrogression as being associated with shear zones in which Nag. 1 age schistose amphibolite dykes are invariably present. Our observations indicate that while retrogression is commonly associated with shear zones, the relationships between basic dykes and shear zones are highly variable. Examples of amphibolite facies retrogression adjacent to basic dykes which are, and are not, related to shear zones are illustrated in figs $5 \& 6$. However, the basic dykes are usually either foliated throughout or have schistose margins and in some cases their complex asymmetrical shapes appear to indicate a syn-tectonic emplacement (cf. Escher et al., 1976; Bridgwater et al., 1977). In such cases deformation presumably did play a part in producing dyke-associated retrogression.

However, despite the intimate association of shear zones, retrogression and basic dykes at many localities (figs $5 \& 10$ ) other examples indicate that this is not always the case. In the ridge to the north of Kristian Gletscher, for example, and elsewhere in that region, abundant basic dykes occur in brown granulite facies gneisses which show neither associated shearing nor retrogression. In the Pourquoi Pas Gletscher - Champs Elysées Gletscher area, garnetiferous metadolerite dykes in general appear to be associated with retrogression zones (fig. 6) but thin dykes are clearly oblique to retrogression zones (fig. 7). In other places, for example in Schweizerland, it is clear that similar dykes that occur in zones of retrogression have themselves been folded (fig. 8). In some cases, large dykes seem to pass from unretrogressed granulite facies gneisses into splayed thin dyke sets in shear zones, but are themselves not sheared. They are, however, locally deformed by later dextral shear zones which cut across the retrogression zone (fig. 9). These various relationships

4ig. 6. Massif on the north side of Pourquoi Pas Gletscher showing rather homogeneous, predominantly granulite facies gneisses cut by a swarm of dark amphibolite dykes. Pale retrogressed zones of various widths occur; a major one is seen on the right just above the glacier. Master basic dykes are associated with retrogression zones. Height of summits in the background are at about $2500 \mathrm{~m}$; glacier is at about $1200 \mathrm{~m}$ a.s. 1 . Arrow indicates the dyke termination that is illustrated in detail in fig. 7 . 
Fig. 7. A set of thin offshoots (c. $2 \mathrm{~m}$ wide) from a larger basic dyke (c. $30 \mathrm{~m}$ wide) discordant to pale-weathering retrogression zones in dark granulite facies gneiss. North side of Pourquoi Pas Gletscher; for precise location see fig. 6 .

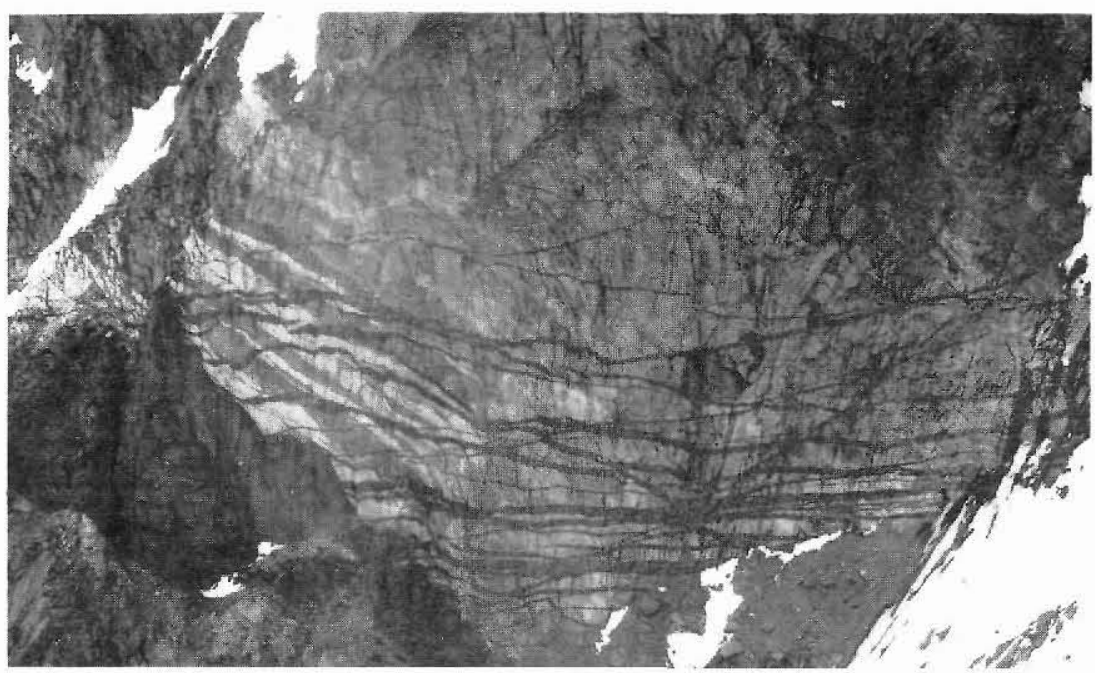

Figure 10 is a field sketch of a shear zone previously illustrated by Myers (1984, fig. 11). A comparison of the figures shows some significant differences in interpretation. Our sketch (NJS) indicates that the new foliation does not cut discordantly across the weaker Archaean fabric, but shows the latter becoming transposed into parallelism with the dykes, one of which occupies an intense shear zone. This relationship has been observed in other shear zones and suggests that the foliation in gneisses further south within the mobile belt is not necessarily a new Proterozoic shear zone fabric as seems to be implied by Bridgwater \& Myers' (1979) interpretation, but is a transposed and intensified Archaean fabric. Elsewhere, the marked contrast between well fo-
Fig. 8. Tightly folded and boudinaged basic dykes within retrogressed granulite facies gneisses with a younger set of disrupted and thinned dykes approximately parallel to the axial plane of the main fold. Thick boudinaged dyke in lower part of photograph is c. $3 \mathrm{~m}$ wide. NE-trending ridge due north of Charcot Fjelde, eastern Schweizerland.

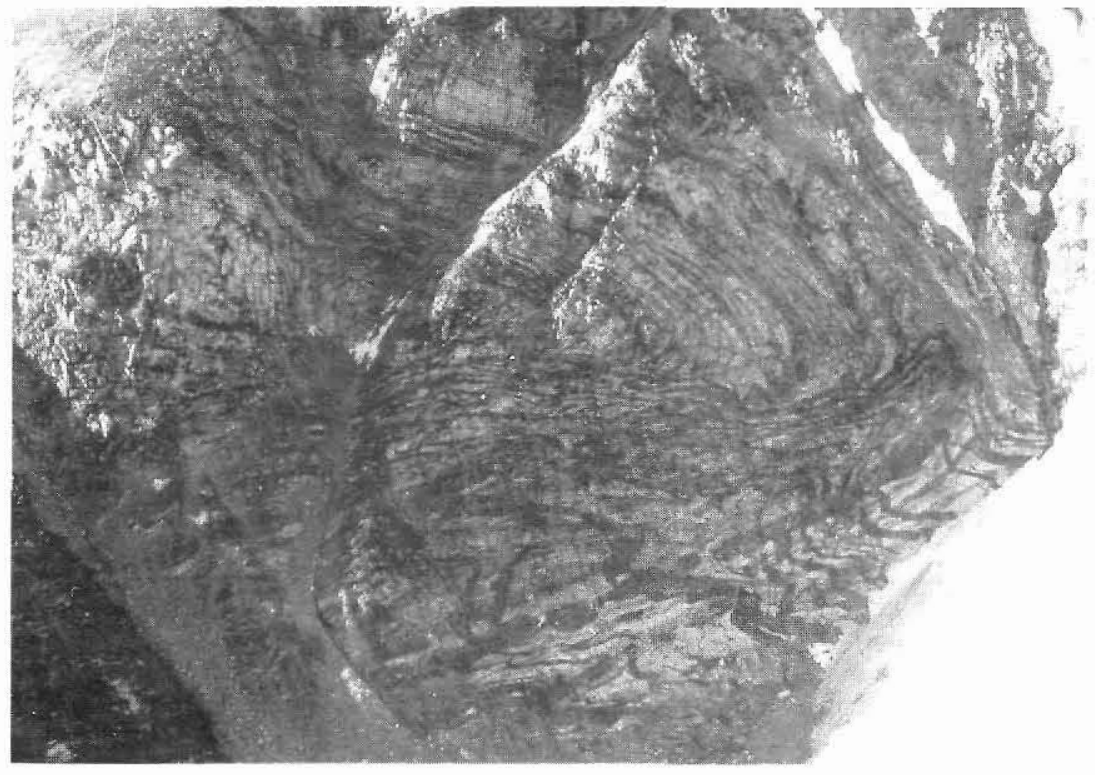




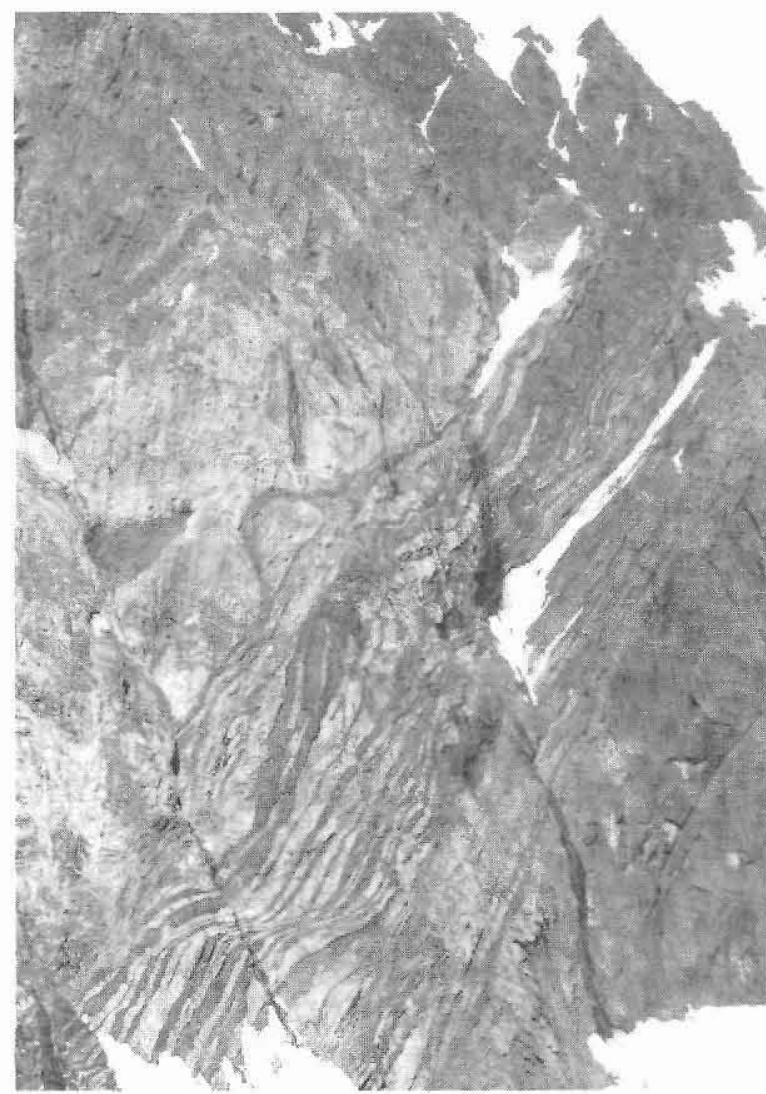

Fig. 9. A swarm of deformed thin offshoots from a larger basic dyke within a pale-weathering zone of retrogression and shearing, deformed by a later low-angle dextral shear (just above snow fan). Width of dyke swarm is about $20 \mathrm{~m}$. View east to $\mathrm{N}-\mathrm{S}$ spur on the southern side of the NE-trending ridge north of Charcot Fjelde, eastern Schweizerland.

liated and banded grey gneisses occupying shear zones and the nebulitic fabric of the host granulite facies rocks clearly suggests the development of a new fabric.

The manner in which the Archaean foliation curves into the shear zone shown in fig. 10 indicates a steep north-side up sense of displacement. Our limited observation of similar relationships and also steeply plunging stretching lineations in gneisses and basic dykes support this general displacement geometry. However, our observations may not be representative of the entire region. Previous workers have recorded other displacement directions on early dislocations. For instance, in the outer coast region, Bridgwater et al. (1977, p. 81) state that a north-down sense of displacement on steep to vertical faults and shears (Nag. 1) is "most common although not exclusive". In their regional appraisals of the mobile belt Bridgwater \& Myers (1979, p. 10) conclude that the "maximum extension within the vertical shear zones is sub-horizontal and the movements are transcurrent" while Myers (1984) developed a tectonic model in which the Nag. 1 steep belts with pronounced planar fabrics are associated with regional dextral transcurrent movements. We have found no evidence of important dextral transcurrent displacement in the shear zones examined by us.

(4) The youngest retrogression of the gneisses is possibly of Tertiary age. The coastal region north of Nigertuluk (to as far as Kangerdlugssuaq) is occupied by a zone of grey gneisses about $10 \mathrm{~km}$ wide, which passes inland into variably retrogressed granulite facies rocks. The coastal gneisses were regarded by Bridgwater et al. (1978) as retrograde amphibolite facies rocks of Archaean age. However, the zone coincides with the densest development of brown-weathering dolerite dykes of supposed Tertiary age, and the possibility must be considered that the retrogression is of the same age as these completely unaltered, undeformed basic dykes. Individual basic dykes which cut the brown gneisses further inland often show grey contact zones, as do supposed Tertiary dykes further south in the mobile belt, where the contact zones are in epidote-amphibolite facies (Escher et al., this volume). The mineralogy of these zones is not known and the coastal zone of presumed amphibolite facies retrogression requires further study.

\section{The northern Proterozoic 'front'}

As reviewed earlier, the northern Proterozoic front was defined by previous workers as outcropping at the coast in a steep shear zone on the south side of the peninsula of Kap Japetus Steenstrup (Wager's, 1934 , 'granulization' zone) from where it was portrayed, to as far as the Inland Ice north-west of Sermilik, as a folded shear zone.

According to our observations, the coastal shear zone is indeed deformed by a large southward closing fold which deforms the multiphase structures in prominent amphibolite dykes, producing generally steep but variable dips (fig. 11). Shear and retrogression zones are also tightly folded in the western inland region near Niflheim (fig. 12). The coastal shear zone, as noted by Wager (1934), is associated with retrogression, but it does not delimit contrasting metamorphic terrains and regionally it cannot be regarded as defining the front of the mobile belt. Partially retrogressed granulite facies rocks and thorough-going amphibolite facies gneisses occur both north and south of it, and locally near the western end of the peninsula east of Nordfjord, the shear zone brings grey gneisses to the north into contact with patchily retrogressed granulite facies gneisses to the south (fig. 3).

According to previous maps (Bridgwater \& Myers, 

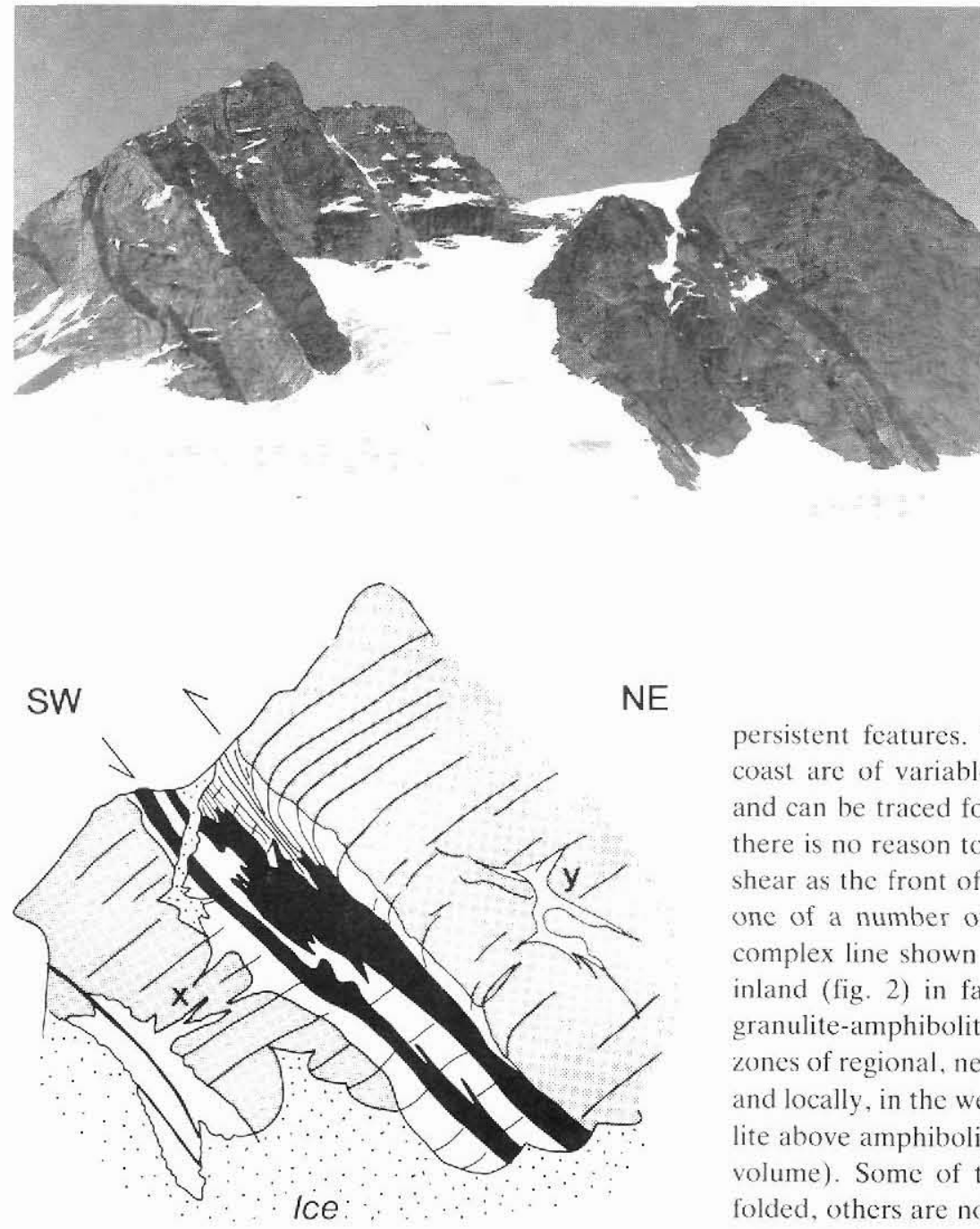

1979; Myers et al., 1979, 1980) the Kap Japetus Steenstrup shear zone east of Nordfjord swings to the west across Kangertigtivatsiaq (fig. 2). Our mapping shows that the main shear zone continues in a WNW direction across Nordfjord where it bifurcates and appears to die out east of Kangertigtivatsiaq (fig. 3). This Nordfjord shear zone has been previously mapped by Bridgwater et al. $(1977$, p. 80$)$ as a "several hundred metre wide retrogressed ductile shear zone bordered by granulitefacies rocks", having a north-side down geometry. It is noteworthy that the shear zone is more or less along strike with the prominent physiographic lineament followed by inner Kangertigtivatsiaq and Glacier de France, a feature that may have influenced Wager (1934) in suggesting that the WNW shear zone could be an important tectonic line.

The steep shear zones seen by us are not regionally
Fig. 10. Above: View from the south-east of twin peaks in the western end of Henry Leon Bjerg massif (fig. 11 in Myers, 1984) showing amphibolite dykes cutting dominantly brown granulite facies gneisses. Retrogression has occurred in shear zoncs parallel to dykes, parallel to regional foliation and in network or patchy areas. Below: ficld sketch (NJS) of the eastern outcrop illustrating transposition of regional gneiss foliation into the shear zone with irregular syn-tectonic dykes and associated retrogression. Retrogression parallel to foliation seen at $\mathrm{x}$; networktype at $y$. Height of outcrop above the glacier is about $400 \mathrm{~m}$.

persistent features. The most prominent zones at the coast are of variable trend (mainly ENE and WNW) and can be traced for no more than $20 \mathrm{~km}$. Therefore, there is no reason to select the Kap Japetus Steenstrup shear as the front of the mobile belt; it represents only one of a number of such shear zones. Similarly, the complex line shown representing the boundary further inland (fig. 2) in fact encompasses different types of granulite-amphibolite facies gneiss contacts, including zones of regional, network and shear zone retrogression and locally, in the west, a thrust contact between granulite above amphibolite facies rocks (Escher \& Hall, this volume). Some of the shear zones in this region are folded, others are not deformed and still other zones of retrogression show little evidence of shearing. The previously published northern mobile belt boundary line represents an arbitrary line within a complex broad transition zone between granulite and amphibolite facies rocks and various types and ages of structures and styles of retrogression which are not necessarily related.

\section{Map depiction of the boundary}

A simplified compilation map of the northern boundary of the Proterozoic mobile belt is presented here in fig. 3. The interplay of the four styles of retrogression described earlicr presented mapping problems in view of the large extent and extreme topography of the area covered by these transitional rocks. Our mapping is based on an attempt to estimate the percentage of granulite and retrogressed amphibolite facies material present. predominantly on the basis of the contrast in colour between brown granulite and grey amphibolite fa- 


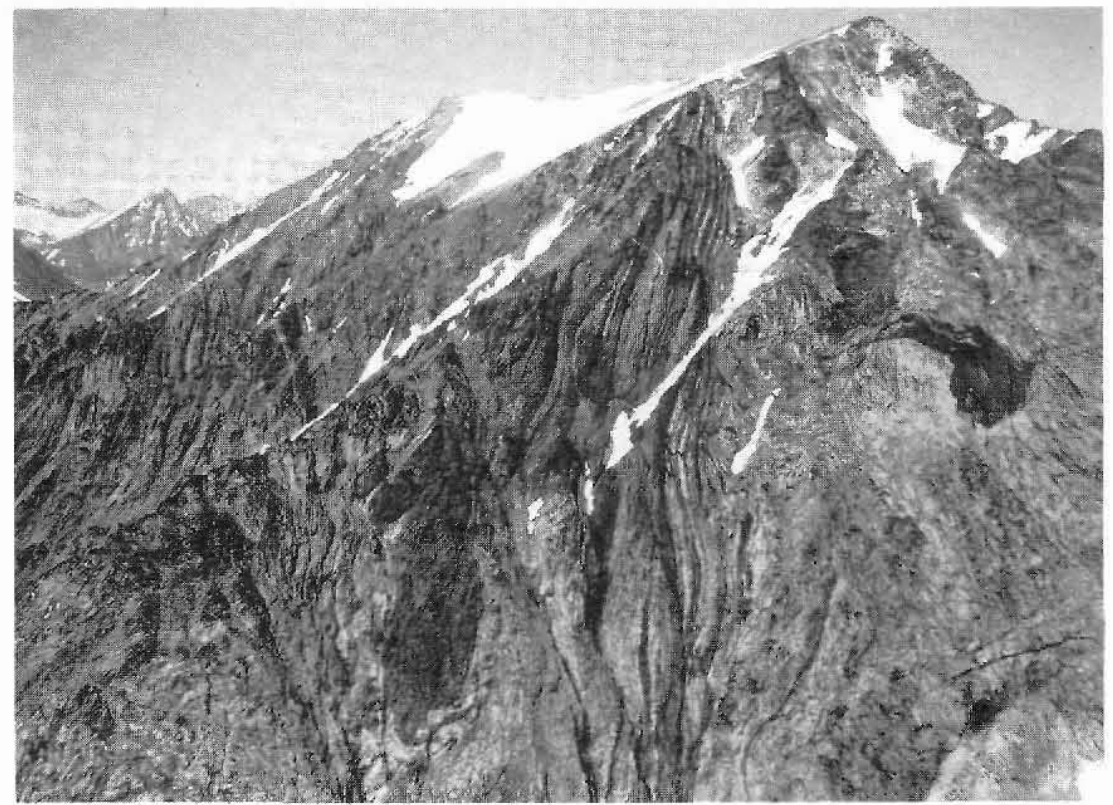

Fig. 11. The Kap Japetus Steenstrup shear zone at the mouth of Kangertigtivatsiaq viewed to the west. Retrogressed granulite facies gneisses with basic dyke relicts on the right deformed by a near vertical shear zone in which basic material and gneiss foliation are brought into parallelism. This is Wager's zone of granulitization and shearing and the Nagssugtoqidian front of Bridgwater \& Myers (1979). Height of the section about $400 \mathrm{~m}$.

cies gneisses. At the predetermined mapping scale $(1: 150000)$ a tripartite division of the gneisses was found to be the most convenient.

Previous published maps essentially distinguish only two gneiss categories - granulite facies and amphibolite facies (fig. 2). In previous mapping 'patchy granulites' or 'granulite facies breccia' (our mixed gneiss category) were included in the granulite facies terrain and only gneisses totally lacking in granulite facies relicts were mapped as grey, amphibolite facies gneisses (J. S.
Myers, personal communication, 1986). This difference in mapping approach, mainly governed by the varying time available (initial mapping of the boundary inland was accomplished on a single helicopter traverse, Myers et al., 1979), serves to accentuate the difference in the interpretations of the boundary: two metamorphic terrains separated by a discrete shear zone boundary, in contrast to our interpretation of the boundary as a very wide heterogeneous zone of retrogression.

Myers et al. (1980) mapped areas of Proterozoic de-

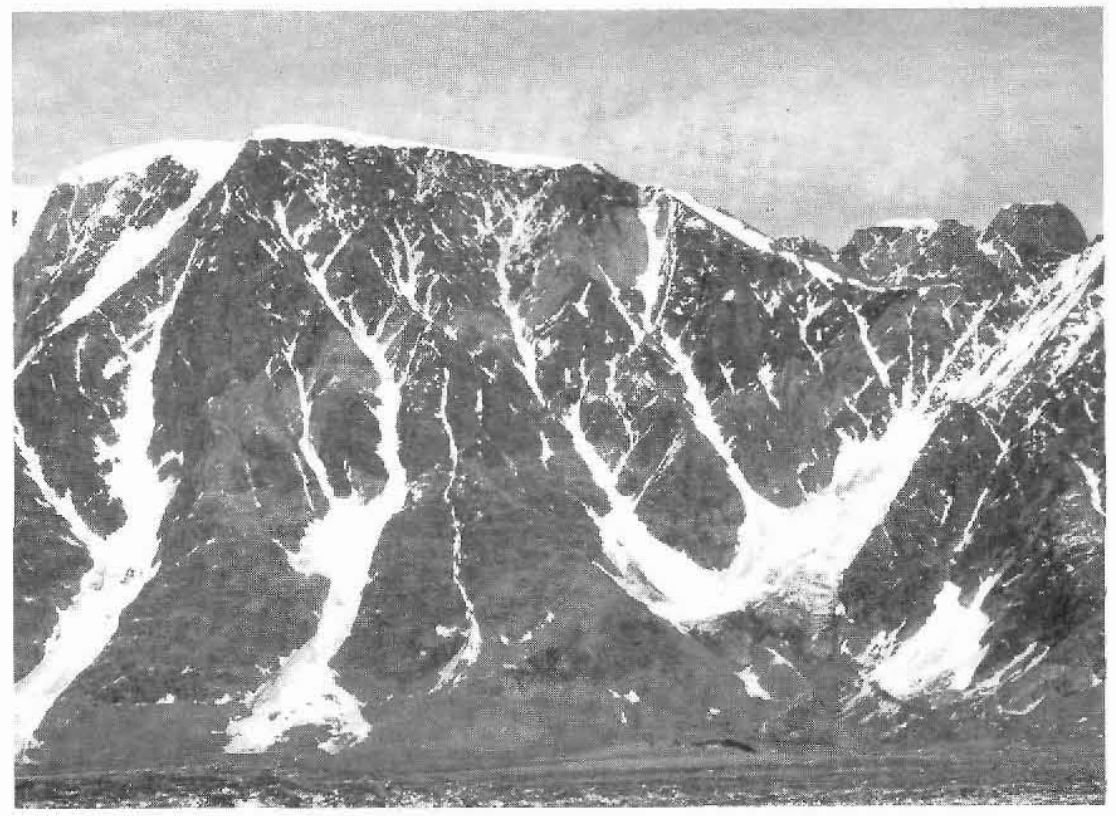

Fig. 12. Retrogression zones in granulite facies gneiss. The zone in the centre in the order of 100 $\mathrm{m}$ thick is tightly folded into an almost recumbent structure that has an axial plane dipping very gently north-westwards and an amplitude in the order of $1 \mathrm{~km}$. View looking eastwards across Fenris Gletscher; ridge is c. 1000 $m$ high. 
formation up to $80 \mathrm{~km}$ north of the northern margin of the belt (fig. 2), while Bridgwater et al. (1978a) noted similar belts of high deformation and amphibolite facies gneisses in the coastal region as far north as Kangerdlugssuaq $\left(68^{\circ} 20^{\prime} \mathrm{N}\right)-300 \mathrm{~km}$ north of the margin. However, this appreciable reworking north of the Kap Japetus Steenstrup shear margin was not featured in regional descriptions of the Proterozoic mobile belt (Bridgwater \& Myers, 1979; Myers, 1984, 1987). Our cursory mapping of the inland nunatak terrain as far north as $67^{\circ} 50^{\prime} \mathrm{N}$ suggests that retrogression occurs sporadically throughout the Archaean block although the age of the retrogression and associated deformation is as yet uncertain.

\section{Conclusions}

We conclude that the northern boundary of the Proterozoic mobile belt is a zone of heterogeneous retrogression and deformation more than $50 \mathrm{~km}$ wide; sporadic but important retrogression occurs also further to the north. Retrogression took place in several stages. An early stage involved regional and pervasive retrogression along anastomosing networks unrelated to basic dyke orientation or shear zone development. Subsequently, retrogression occurred associated with the intrusion of probably several generations of dykes, some of which were emplaced syntectonically during shear zone development. The main displacement of the northern Archaean block appears to have been upwards and to the south, above the commonly lower-grade part of the mobile belt.

Contrary to previous interpretations, none of the shear zones seen by us can be regarded as anything other than local tectonometamorphic boundaries. Any attempt to delimit structural or metamorphic terrains within the northern boundary zone must be necessarily arbitrary.

Acknowledgement. PRD thanks John S. Myers (Geological Survey of Western Australia, Perth) for post-season discussions in Perth on the geology of the northern boundary. 